\title{
Remarks on the Diversity of Theoretical Perspectives in Language Policy Research
}

\section{Notas sobre a diversidade de perspectivas teóricas em pesquisas sobre política linguística}

Leandro Rodrigues Alves Diniz*

*Federal University of Minas Gerais (UFMG), Belo Horizonte, Minas Gerais / Brazil leandroradiniz@gmail.com

https://orcid.org/0000-0002-7128-7243

Elias Ribeiro da Silva**

**Federal University of Alfenas (UNIFAL), Alfenas, Minas Gerais / Brazil

ribeirodasilva.elias@gmail.com

https://orcid.org/0000-0003-0718-9478

\begin{abstract}
In this article, which opens the second issue of Volume 19 of Revista Brasileira de Linguistica Aplicada, we discuss some existing epistemological divergences in language policy research. In the first section, two lines of divergence will be outlined: (i) the focus on official versus de facto language policies; (ii) the conception of language policymakers versus subjects of language policies. In the second section, based on the analysis of titles of thematic issues, dossiers and books recently published in Brazil, we argue that this diversity of perspectives may be clearly noticed in the research carried out in the country. We finish our text highlighting some issues that have gained strength in the Brazilian research agenda.
\end{abstract}

KEYWORDS: language policy research; epistemological divergences; official language policy; de facto language policy; policymakers; Brazilian language policies.

RESUMO: Neste artigo, que abre o segundo número do volume 19 da Revista Brasileira de Linguística Aplicada, discutimos algumas divergências epistemológicas existentes nas pesquisas sobre política linguística. Na primeira seção, esboçamos duas linhas de divergência: (i) o foco nas políticas linguísticas oficiais versus nas de facto; (ii) a concepção de atores versus sujeitos de políticas linguísticas. $\mathrm{Na}$ segunda seção, com base na análise de títulos de números temáticos, dossiês e livros publicados recentemente no Brasil, argumentamos que essa diversidade de perspectivas pode ser claramente observada nas pesquisas desenvolvidas no país. Terminamos nosso texto destacando alguns temas que vêm ganhando força na agenda de pesquisa brasileira. 
PALAVRAS-CHAVE: Pesquisa em política linguística; divergências epistemológicas; política linguística oficial; política linguística de facto; atores de política linguística; políticas linguísticas brasileiras.

\section{Introduction}

Given the multifaceted nature of the social phenomena with which they are concerned, research on language policy - as it is common in Human and Social Sciences - is marked by a series of less or more noticeable disputes. Presented either as related to a specific area of knowledge or as an object of study in more clearly institutionalized areas (such as Sociolinguistics, Applied Linguistics, or Discourse Analysis), such investigations also reveal divergences in the definition of key aspects.

In this sense, the term "language planning and policy" is used in the English-language literature as a way of naming a specific area of knowledge, ${ }^{1}$ as it appears, for example, in the book Language Policy and Language Planning: from nationalism to globalization (WRIGHT, 2003). The use of this complex noun phrase is a trace of a perspective which separates the decisionmaking concerning a given sociolinguistic situation (named in this tradition as "language policy") from its implementation (referred to as "language engineering" or, more commonly, "language planning"). ${ }^{2}$ However, New Zealander author Bernard Spolsky (2004), as well as US researchers Thomas Ricento (2006) and Elana Shohamy (2006), have used the term "language policy” to name the area. Based on the discussions held by Shohamy (2006),

\footnotetext{
${ }^{1}$ For a history of the terms "language planning" and "language policy", as well as some of its correlates in other languages, see the work of Frenchman Louis-Jean Calvet (2007). ${ }^{2}$ Note, however, that the addition of the term "policy" to the noun phrase as a way of naming the area is recent. Since its origin in the middle of the 20th century, the wellestablished term was "language planning", because it was understood it was a technical field developed by researchers in the area of Sociolinguistics aimed at solving linguistic problems in different parts of the world. This view may be observed, for instance, when Crystal (1992, p. 310-311) defines language planning as "[a] deliberate, systematic, and theorybased attempt to solve the communicative problems of a community by studying the various languages or dialects it uses, and developing the policy concerning their selection and use; also sometimes called language engineering or language treatment'.
} 
for example, we can conclude that the choice of this term aims to emphasize the political dimension of such practices. ${ }^{3}$

Precisely with the purpose of shedding light on divergences such as the one presented above, we propose this article, which opens the second issue of Volume 19 of the Revista Brasileira de Linguistica Aplicada. Evidently, we do not have the illusory pretension to exhaustively discuss all the differences that may be observed in different research traditions on language policy. It is only a matter of outlining some epistemological contours through the establishment of points of approximation and differentiation between some research traditions. In this way we hope our text will somehow contribute to make these contours more visible - either in the articles of the present issue, or in other publications - so that they can be questioned and redesigned as necessary.

This article is organized in two main sections, in addition to the present introduction and the final considerations. In the first one, we discuss some epistemological divergences in the research on language policies. Two lines of divergence will be outlined: (i) the focus on official versus de facto language policies; (ii) the conception of language policymakers versus subjects of language policies. In the second section, based on the analysis of titles of thematic issues, dossiers and books recently published in Brazil, we argue that this diversity of perspectives is also at play in the research carried out in the country. We finish our text highlighting some issues that have gained strength in the Brazilian research agenda on language policies.

\section{Epistemological Divergences in Research on Language Policy}

In this section we will firstly discuss what we recognize to be the two main research trends in the field of language policy regarding the focus of analysis: the official/explicit versus the de facto/implicit language policy. Afterwards, we will contrast two views concerning those who are generally named as "policymakers".

\footnotetext{
${ }^{3}$ For a more in-depth discussion of this epistemological difference, see, among others, Wiley (1996), Ribeiro da Silva (2011, 2013), and Johnson (2013).
} 


\subsection{Official Language Policy versus De Facto Language Policy}

In the specialized literature it is often said that language policy is concerned with decision-making in order to set out, promote, or prohibit the use of a language or a language variety. ${ }^{4}$

This understanding is also present in Calvet's (2007) work, who argues that language policy refers to "the determination of the major decisions concerning the relations between languages and society" (2007, p. 11, our translation). Under the entry "Language Planning" in the International Encyclopedia of Linguistics (BRIGHT, 1992), Jahr points out that

LP [Language Planning] refers to an organized activity (private or official) which attempts to solve language problems within a given society, usually at the national level. Through LP, attempts are made to direct, change, or preserve the linguistic norm or the social status (and communicative function) of a given written or spoken language, or variety of a language. LP is usually conducted according to a declared program or defined set of criteria, and with a deliberate goal - by officially appointed committees or bodies, by private organizations, or by prescriptive linguists working on behalf of official authorities. Its objective is to establish norms (primarily written) which are validated by high social status; oral norms connected with these standards follow (JAHR, 1992, p. 12-13).

Based on these definitions, it is possible to affirm that language policy would involve the conscious and purposeful intervention of an agent in a specific sociolinguistic context. By implication, the analysis of the politicallinguistic situation of a specific community would be carried out, mainly, by the examination of its official documents, i.e, its formalized and explicit language policy. However, several authors have recently argued that language policy made explicit by official documents may not coincide with the one that takes place in society (see, e.g., SCHIFFMAN, 1996; SPOLSKY, 2004; SHOHAMY, 2006).

Schiffman (1996) proposes that there can be two simultaneous language policies in a given sociolinguistic context: an explicit (overt) and an implicit (covert) one. Explicit language policy concerns official legislation on linguistics issues, whereas implicit language policy refers to linguistic rules

\footnotetext{
${ }^{4}$ From a certain point of view, what counts as "language" or "language variety" may also be considered a matter of language policy, and not one of mere "language realities".
} 
that are not formalized yet manifested in social practices and sanctions. This distinction drawn by Schiffman is key to language policy investigations once it highlights the possible contradictory character of the official policies of several societies. Based on this distinction, Schiffman proposes that language policy is strongly related to the linguistic culture of a society. In this own words,

It should be clear by now that the basic tenet of this book is that language policy is ultimately grounded in linguistic culture, that is, the set of behaviours, assumptions, cultural forms, prejudices, folk belief systems, attitudes, stereotypes, ways of thinking about language, and religio-historical circumstances associated with a particular language (SCHIFFMAN, 1996, p. 5).

The same author argues that the beliefs of a certain language community regarding its own mother tongue can determine its attitudes toward other languages. Thus, these beliefs may influence this community language maintenance and transmission while stimulating or discouraging the teaching and learning of additional languages. Such understanding of language policy has considerable implications for conducting research in the area, since it suggests the investigations should also focus on implicit language policies, rather than focusing on just explicit ones. In order to do so, it would be necessary to investigate the community's linguistic beliefs considering its social history, which constitutes a tough methodological challenge.

Spolsky (2004) and Shohamy (2006) also propose the existence of both formal and informal language policies. These authors also claim that a language policy can exist independently of an agent who promotes it explicitly. According to Spolsky,

$[\ldots]$ language policy exists even where it has not been made explicit or established by authority. Many countries and institutions and social groups do not have formal or written language policies, so that the nature of their language policy must be derived from a study of their language practice or beliefs. Even where there is a formal, written language policy, its effect on language practices is neither guaranteed nor consistent. (SPOLSKY, 2004, p. 8). 
From this expanded conception of language policy, Shohamy (2006) proposes that " [...] de facto policies are determined somewhere else, by a variety of mechanisms that indirectly perpetuate LPs [Language Policies] and that serves as a tool to turn ideologies, mostly in the traditional nationstates, into homogeneous and hegemonic policies" (SHOHAMY, 2006, p. 57). According to the author, mechanisms are the channels through which policies are disseminated and / or reproduced in society. Therefore, they incorporate the hidden agendas of the language policy, and explicitly and / or implicitly act in its operation. The official language policy of a country, expressed in a legislative text, is considered an example of an explicit mechanism, whereas teaching materials, language exams, traffic signs, proper names (of people, shops and objects etc.), clothing, among others, are regarded as implicit mechanisms.

The two perspectives discussed in this section are not exclusionary. They may, and in many cases they must, complement each other. What we wished to emphasize when discussing them is that the researcher willing to understand the language policy in force in a society must often look beyond its official language policy and seek to understand what Shohamy (2006) calls de facto language policy and its hidden agendas.

\subsection{Language Policymakers Versus Subjects of/ to Language Policies}

The studies undertaken by authors like Schiffman (1996), Spolsky (2004), and Shohamy (2006), briefly presented in section 1.1, have made visible an important theoretical movement to take into account other policymakers in addition to the official ones. Another movement observed in some studies on language policies concerns the very nature of those who are generally named as "policymakers".

In order to shed light on this point, we would firstly like to recall the definition of "language planning" given by Cooper (1989). Based on the question "Who plans what for whom and how?", this American author argues that such term "refers to deliberate efforts to influence the behavior of others with respect to the acquisition, structure, or functional allocation of their language codes" (1989, p. 45, emphasis added). Likewise, when opposing "language policy" to "language planning", Calvet (2002, p. 145) defines the former as "a set of conscious choices regarding the relations between language (s) and social life" (our translation, emphasis added). As it usually happens in 
the research on language policy, both of these definitions reveal the typical psychological conception of the subject.

Such conception is in striking contrast with the one that we may note in the studies on language policy carried out in the field of History of Linguistic Ideas in Brazil (ORLANDI, 2001), which bears a strong relationship with Discourse Analysis (PÊCHEUX, 1997). ${ }^{5}$ According to this perspective, marked by Psychoanalysis and Historical Materialism, the subject is "split", driven by the unconscious and ideology, for which reason he/she is not the origin of "his/her" discourses. Since the subject does not have complete control over his/her utterances, neither is he/she capable of planning and implementing a language policy according to his/ her "own" wishes. That is why, as stated in previous studies (DINIZ, 2012, 2013), the so-called "policymakers" should be viewed, in such discursive perspective, as subjects of language policies, who are also subject to the policy of languages ${ }^{6}$ which is constitutive of each and every space of enunciation (GUIMARÃES, 2002). Since they are socio-ideologically constituted, one's "deliberate efforts" or "conscious choices" - to retake Cooper's and Calvet's words - concerning a given language policy are irrelevant to this theoretical framework. It is what "escapes" from the official planning, from the "policymakers"' own intentions, that mostly grabs research attention in this discursive tradition.

In short, contrary to the epistemological differences discussed in section 1.1, which result from the very process of theorizing about language policy, the divergences on which we have just focused seem to stem from previous theoretical background, concerning not exactly how the concept of "language policy" itself is regarded, but rather how "language" and "policy", separately, are understood in this term.

\section{The Diversity of Research Perspectives on Language Policy in Brazil}

The epistemological divergences discussed in the previous section may also be noticed in research on language policies developed in Brazil. In order to support this argument, we have listed in Tables 1 and 2 , respectively,

\footnotetext{
${ }^{5}$ For a more detailed discussion about this relationship, see Diniz (2012, 2013, in press). ${ }^{6}$ In Portuguese: "política de línguas". This term is used by Orlandi (2007) to emphasize the inexorable political nature of the language(s).
} 
data from special issues and dossiers of journals and books published in Brazil over the last few years, which explicitly refer to "language policy" or similar expressions. We emphasize that we do not aim to make an exhaustive survey of these publications, but rather raise some points to contribute to the discussion that interests us in this article.

TABLE 1 - Some Special Issues and dossiers in Recent Journals on Language Policy

\begin{tabular}{|c|c|c|c|}
\hline Journal / Institution & Title of the Special Issue/ Dossier & $\begin{array}{l}\text { Volume / } \\
\text { Number }\end{array}$ & Year \\
\hline $\begin{array}{l}\text { Letras - Federal University } \\
\text { of Santa Maria (UFSM) }\end{array}$ & $\begin{array}{l}\text { Language policies: spaces, questions and agendas } \\
\text { (In the original: Politicas linguísticas: espaços, } \\
\text { questões e agendas) }\end{array}$ & Vol. 21, n. 42 & 2011 \\
\hline $\begin{array}{l}\text { Gragoatá - Fluminense } \\
\text { Federal University (UFF) }\end{array}$ & $\begin{array}{l}\text { Language policy and planning } \\
\text { (In the original: Política e planificação } \\
\text { linguística) }\end{array}$ & Vol. 32 & 2012 \\
\hline $\begin{array}{l}\text { Revista Brasileira de } \\
\text { Linguistica Aplicada } \\
\text { (RBLA) - Federal } \\
\text { University of Minas } \\
\text { Gerais (UFMG) and } \\
\text { Brazilian Association } \\
\text { of Applied Linguistics } \\
\text { (ALAB) }\end{array}$ & Language Policy and Planning & Vol. 12, n. 2 & 2012 \\
\hline \multirow{3}{*}{$\begin{array}{l}\text { Trabalhos em Linguistica } \\
\text { Aplicada (TLA) - State } \\
\text { University of Campinas } \\
\text { (Unicamp) }\end{array}$} & No specific title. & Vol. 51, n. 2 & 2012 \\
\hline & No specific title. & Vol. 52, n. 2 & 2013 \\
\hline & $\begin{array}{l}\text { Language policies and identity politics in } \\
\text { indigenous contexts } \\
\text { (In the original: Politicas linguisticas e } \\
\text { politicas de identidade em contextos indigenas) }\end{array}$ & Vol. 57 , n. 3 & 2018 \\
\hline $\begin{array}{l}\text { Revista } X-\text { Federal } \\
\text { University of Paraná } \\
\text { (UFPR) }\end{array}$ & $\begin{array}{l}\text { Portuguese as an Additional Language in } \\
\text { minority contexts: (co)constructing meanings } \\
\text { from the margins } \\
\text { (In the original: Português como Lingua } \\
\text { Adicional em contextos de minorias: (co) } \\
\text { construindo sentidos a partir das margens) }\end{array}$ & Vol. 13, n. 1 & 2018 \\
\hline
\end{tabular}

Source: Table organized by the authors. 
TABLE 2 - Some Books on Language Policy

\begin{tabular}{|c|c|c|c|}
\hline Editors / Authors & Title of the Book & City / Publisher & Year \\
\hline $\begin{array}{l}\text { Nicolaides; Silva; Tilio; } \\
\text { Rocha (ed.) }\end{array}$ & $\begin{array}{l}\text { Language policy and policies } \\
\text { (In the original: Política e politicas } \\
\text { linguisticas) }\end{array}$ & Campinas, Pontes & 2013 \\
\hline Correa (ed.) & $\begin{array}{l}\text { Language policy and language teaching } \\
\text { (In the original: Politica linguistica e ensino } \\
\text { de lingua) }\end{array}$ & Campinas, Pontes & 2014 \\
\hline Freitag; Silva (ed.) & $\begin{array}{l}\text { Routes of a language policy in Brazil } \\
\text { (In the original: Percursos de uma politica } \\
\text { linguística no Brasid) }\end{array}$ & Jundiaí, Paco & 2015 \\
\hline Sousa; Roca (ed.) & $\begin{array}{l}\text { Language policies: declared, practiced and } \\
\text { perceived } \\
\text { (In the original: Politicas linguisticas: } \\
\text { declaradas, praticadas e percebidas) }\end{array}$ & João Pessoa, UFPB & 2015 \\
\hline Lourenço & $\begin{array}{l}\text { Public language policy versus inclusive education } \\
\text { (In the original: Politica pública linguística } \\
\text { versus educação inclusiva) }\end{array}$ & $\begin{array}{l}\text { Joinville, Asè } \\
\text { Editorial }\end{array}$ & 2016 \\
\hline $\begin{array}{l}\text { Freitag; Severo; Görski } \\
\text { (ed.) }\end{array}$ & $\begin{array}{l}\text { Sociolinguistics and Language Policy: } \\
\text { contemporary views } \\
\text { (In the original: Sociolinguística e Politica } \\
\text { Linguística: olhares contemporâneos) }\end{array}$ & São Paulo, Blucher & 2016 \\
\hline $\begin{array}{l}\text { Oliveira; Rodrigues } \\
\text { (ed.) }\end{array}$ & $\begin{array}{l}\text { Minutes of the VIII International Meeting of } \\
\text { Language Policy Researchers Language policy } \\
\text { (In the original: Atas do VIII Encontro } \\
\text { Internacional de Investigadores de Politicas } \\
\text { Linguisticas) }\end{array}$ & $\begin{array}{l}\text { Florianópolis, } \\
\text { UFSC/AUGM }\end{array}$ & 2017 \\
\hline Sousa; Roca; Ponte (ed.) & $\begin{array}{l}\text { Language policy issues in the regional } \\
\text { integration process } \\
\text { (In the original: Temas de politica linguística } \\
\text { no processo de integraşão regional) }\end{array}$ & Campinas, Pontes & 2018 \\
\hline Lagares & $\begin{array}{l}\text { Which language policy? Contemporary } \\
\text { glotopolitical challenges } \\
\text { (In the original: Qual politica linguística? } \\
\text { Desafios glotopoliticos contemporâneos) }\end{array}$ & São Paulo, Parábola & 2018 \\
\hline
\end{tabular}

Source: Table organized by the authors. 
Firstly, we would like to focus on the title "Language Policy and Planning", which names both volume 32 of Gragoatá (2012) and the issue 2 of volume 52 of Revista Brasileira de Linguistica Aplicada (2012). This title explicitly mobilizes the binomial "language planning"7 and "language policies" in the wake of the Anglo-American tradition. However, as the titles of the publications listed in Tables 1 and 2 indicate, the term "language policy" predominates in surveys carried out in Brazil, as in the works of Spolsky (2004), Ricento (2006), and Shohamy (2006), cited in the introduction of this article.

It is also worthy of note a possible movement to extend the meaning effects of the term "language policy" in titles such as "Language policy and policies" (NICOLAIDES et al., 2013), through the contrast between singular and plural, and "Language policies: declared, practiced and perceived" (SOUSA, ROCA, 2015), by the specification of three types of language policies in the subtitle. Similarly, in the presentation of issue 2 of volume 52 of Trabalhos em Linguistica Aplicada (2013), the editorial board points out the thematic dossier that integrates the journal deals with "policies of languages and internationalization" [emphasis added]. We would also like to stress that in the presentation of the dossier organized by Bizon and Diniz (2018, p. 3) for Revista $X$ (2018) it is stated that the articles of the publication "focus on policies - the less or the more institutionalized ones - of PLA [Portuguese as an Additional Language]" [emphasis added]. Once again, we note the semantic widening of the term "language policy", this time, through the phrase between dashes.

Still on the basis of the titles presented in Tables 1 and 2, we draw the attention to the approximation (and even the subordination) of Brazilian research on language policies to other theoretical concepts or disciplinary fields: studies on identities, Public Policy, Sociolinguistics, and Glotopolitics, respectively in the cases of "Language policies and identity politics in indigenous contexts" (TRABALHOS EM LINGUÍSTICA APLICADA, 2018), "Language public policy versus inclusive education" (LOURENÇO, 2016), "Sociolinguistics and Language Policy: contemporary views"

\footnotetext{
7 "Language planning" is usually translated into Portuguese as "planejamento linguístico", but "planificação linguística" is also used, as we may observe in Gragoatá (2012).

${ }^{8}$ In Portuguese: "política de línguas e internacionalização" [emphasis added].
} 
(FREITAG; SEVERO; GÖRSKI, 2016), and "Which language policy? Contemporary glotopolytic challenges" (LAGARES, 2018).

Based on the analysis set out in this section, it may be said that the diversity of epistemological perspectives is clearly at play in the studies carried out in Brazil.

\section{Conclusions}

Although Brazil is as a multicultural and multilingual society, research on language policy in the country is strangely underdeveloped, as Oliveira (2007) has noted. However, the strengthening of these kinds of studies in recent years is remarkable, as shown in Tables 1 and 2 above. Language policies at different levels of education are among topics that have been gaining ground in Brazilian research, as it can be seen in the present thematic issue, which includes articles on literacy reforms, the Brazilian National High School Examination (ENEM), and the Federal Program Languages Without Borders. Debates over language policies in the process of internationalization of Brazilian higher education have also gained more space and are present in this edition of the Revista Brasileira de Linguistica Aplicada as well.

Additionally, it is possible to observe an increase in the number of studies on language policies related to the teaching of Portuguese as an Additional Language (DINIZ, 2012, in press), including those in regard to minority groups such as immigrants and refugees (REVISTA X, 2018). Investigations concerning heritage languages and bilingual education, both in elitist education contexts and in border areas (SILVA, 2011), as well as those regarding the regional integration of Latin America (FANJUL; CASTELA, 2011; SOUSA; ROCA; PONTE, 2018), have also been growing. Policies directed to indigenous peoples (TRABALHOS EM LINGUÍSTICA APLICADA, 2018) and deaf people (LOURENÇO, 2016), among other groups, have been gaining space in research as well. Finally, more and more studies focusing on the Brazilian language policy developed for Spanish (ALVAREZ, 2016) and English (RIBEIRO DA SILVA, 2011), particularly regarding the use of the latter as a medium of instruction in higher education (SARMENTO; LIMA; MORAES FILHO, 2016; BAUMVOL; SARMENTO, 2016), are being carried out in the country.

More than listing language policy topics that have been studied in Brazil, in concluding this first article of the present thematic issue of Revista 
Brasileira de Linguistica Aplicada, we intend to point out that language policy is, on the one hand, a broad and yet under explored field of research and, on the other hand, an important forum of social action for us, Brazilian applied linguists. As Shohamy (2006) points out, the de facto language policy of a society must be widely understood and problematized in order to guarantee the linguistic rights of all its citizens.

\section{Acknowledgements}

The authors would like to thank Ana Paula de Araújo Lopez for the careful language revision of this article. However, we bear full responsibility for the text.

\section{References}

ALVAREZ, M. L. O. (ed.). Políticas de valoriz. (ação) do ensino de espanbol no contexto brasileiro: desafios. Campinas, SP: Pontes, 2016.

BAUMVOL, L. K.; SARMENTO, S. A internacionalização em casa e o uso de inglês como meio de instrução. In: BECK, M. S. B. et al. (ed.). Echoes: Further Reflections on Language and Literature. Florianópolis, SC: UFSC, 2016. p. 65-82. BIZON, A. C. C.; DINIZ, L. R. A. (ed.). Apresentação. Revista X, Curitiba, v. 13, n. 1, p. 1-5, 2018. [Dossiê: Português como Língua Adicional em Contextos de Minorias: (Co)construindo Sentidos a Partir das Margens]. Doi: https://doi. org/10.5380/rvx.v13i1.61248

BRIGHT, W. (ed.). International Encyclopedia of Linguistics. New York; Oxford: Oxford University Press, 1992. v. 4.

CALVET, L.-J. Sociolingüistica: uma introdução crítica. São Paulo: Parábola, 2002.

CALVET, L.-J. As políticas linguísticas. Tradução de Isabel de Oliveira Duarte, Jonas Tenfen e Marcos Bagno. São Paulo: Parábola Editorial; Florianópolis: IPOL, 2007.

COOPER, R. L. Language planning and social change. New York: Cambridge University Press, 1989. Doi: https://doi.org/10.1017/CBO9780511620812

CORREA, D. A. (ed.). Politica linguística e ensino de lingua. Campinas, SP: Pontes, 2014. CRYSTAL, D. Glossary (Language Planning). In: BRIGHT, W. (ed.). International Encyclopedia of Linguistics. New York; Oxford: Oxford University Press, 1992. v. 4, p. 310-311. 
DINIZ, L. R. A. Política linguística do estado brasileiro na contemporaneidade: a institucionalização de mecanismos de promoção da língua nacional no exterior. 2012. Tese (Doutorado em Linguística) - Universidade Estadual de Campinas, Campinas, 2012.

DINIZ, L. R. A. O conceito de "política linguística": reflexões a partir do diálogo entre a história das ideias linguísticas, a análise do discurso e a semântica do acontecimento. In: COSTA, G. C. da; MASSMANN, D. (ed.). Linguagem e bistoricidade. Campinas: RG, 2013. p. 43-58.

DINIZ, L. R. A. Para além das fronteiras: a política linguística brasileira de promoção internacional do português. Belo Horizonte: UFMG. (In press).

FANJUL, A. P.; CASTELA, G. da S. (ed.). Linguas, politicas e ensino na integração regional. Cascavel, PR: ASSOESTE, 2011.

FREITAG, R. M. K.; SEVERO, C. G.; GÖRSKI, E. M. (ed.). Sociolinguistica epolítica linguística: olhares contemporâneos. São Paulo: Blucher, 2016. Doi: https://doi. org/10.5151/9788580391466

FREITAG, R. M. K.; SILVA, L. R. da. (ed.). Percursos de uma politica linguistica no Brasil. Jundiaí, SP: Paco, 2015.

GRAGOTÁ. Universidade Federal Fluminense. Publicação dos Programas de PósGraduação do Instituto de Letras. - Niterói, Rio de Janeiro, v. 32, 2012.

GUIMARÃES, E. R. J. Semântica do acontecimento: um estudo enunciativo da designação. Campinas: Pontes, 2002.

JAHR, E. H. Language Planning. In: BRIGHT, W. (ed.). International Encyclopedia of Linguistics. New York; Oxford: Oxford University Press, 1992. v. 4, p. 412-14.

JOHNSON, D. C. Language Policy. New York: Palgrave Macmillan, 2013.

LAGARES, X. C. Qual política linguística? Desafios golotopolíticos contemporâneos. São Paulo: Parábola, 2018.

LETRAS. Universidade Federal de Santa Maria. Centro de Artes e Letras. Programa de Pós-Graduação em Letras, Santa Maria, Rio Grande do Sul, v. 21, n. 42, 2011.

LOURENÇO, K. R. C. Política pública linguística versus educaşão inclusiva: desvelando processos de exclusão de surdos. Joinville, SC: Asè Editorial, 2016.

NICOLAIDES, C.; SILVA, K. A. da; TÍLIO, R.; ROCHA, C. H. (ed.). Política e politicas linguisticas. Campinas: Pontes Editores, 2013.

OLIVEIRA, G. M. de. Prefácio. In: CALVET, L-J. As políticas linguísticas. São Paulo: Parábola; Florianópolis: Ipol, 2007. p. 7-10. 
OLIVEIRA, G. M. de.; RODRIGUES, L. F. (ed.). Atas do VIII Encontro Internacional de Investigadores de Políticas Linguísticas. Florianópolis: UFSC / AUGM - Núcleo Educação para a Integração, 2017.

ORLANDI, E. P. (ed.) História das idéias linguísticas: construção do saber metalinguístico e constituição da língua nacional. Campinas: Pontes; Cáceres: Unemat, 2001.

ORLANDI, E. P. (ed.). Politica linguística no Brasil. Campinas: Pontes, 2007.

PECCHEUX, M. Semântica e discurso: uma crítica à afirmação do óbvio. Campinas: Unicamp, 1997.

REVISTA BRASILEIRA DE LINGUÍSTICA APLICADA. Universidade Federal de Minas Gerais, Faculdade de Letras, Belo Horizonte, Minas Gerais, v. 12, n. 2, 2012.

REVISTA X. Universidade Federal do Paraná. Departamento de Letras Estrangeiras e Modernas, Curitiba, Paraná, v. 13, n. 1, 2018.

RIBEIRO DA SILVA, E. A pesquisa em política linguística: histórico, desenvolvimento e pressupostos epistemológicos. Trabalhos em Linguística Aplicada, Campinas, v. 52, n. 2, p. 289-320, 2013. Doi: https://doi.org/10.1590/S010318132013000200007

RIBEIRO DA SILVA, E. “[...] Você vai ter que aprender inglês de qualquer jeito, querendo ou não!": exames de línguas e política linguística para o inglês no Brasil. 2011. Tese (Doutorado) -Universidade Estadual de Campinas, Campinas, 2011.

RICENTO, T. (ed.). An Introduction to Language Policy: theory and method. Malden, USA; Oxford, UK: Blackwell Publishing, 2006.

SARMENTO, S.; LIMA, D. A. E.; MORAES FILHO, W. (ed.). Do Inglês sem Fronteiras ao Idiomas sem Fronteiras: a construção de uma política linguística para a internacionalização. Belo Horizonte: UFMG, 2016.

SCHIFFMAN, H. F. Linguistic Culture and Language Policy. London; New York: Routledge, 1996.

SHOHAMY, E. Language Policy: Hidden agendas and new approaches. London; New York: Routledge, 2006. Doi: https://doi.org/10.4324/9780203387962

SILVA, S. de S. (ed.). Linguas em contato: cenários de bilinguismo no Brasil. Campinas: Pontes, 2011.

SOUSA, S. C. T. de; ROCA, M. del P. (ed.). Politicas linguísticas: declaradas, praticadas e percebidas. João Pessoa: UFPB, 2015. 
SOUSA, S. C. T. de; ROCA, M. del P.; PONTE, A. S. (ed.). Temas de política linguística no processo de integração regional. Campinas: Pontes, 2018.

SPOLSKY, B. Language Policy. Cambridge, UK: Cambridge University Press, 2004. TRABALHOS EM LINGUÍSTICA APLICADA. Universidade Estadual de Campinas, Instituto de Estudos da Linguagem, Campinas, São Paulo, v. 51, n. 2, 2012.

TRABALHOS EM LINGUÍSTICA APLICADA. Universidade Estadual de Campinas, Instituto de Estudos da Linguagem, Campinas, São Paulo, v. 52, n. 2, 2013.

TRABALHOS EM LINGUÍSTICA APLICADA. Universidade Estadual de Campinas, Instituto de Estudos da Linguagem, Campinas, São Paulo, v. 57, n. 3, 2018.

WILEY, T. G. Language Planning and Policy. In: MCKAY, S. L.; HORNBERGER, N. H. (ed.). Sociolinguistics and Language Teaching. Cambridge, UK: Cambridge University Press, 1996. p. 103-147.

WRIGHT, S. Language Policy and Language Planning: from nationalism to globalisation. Hampshire, UK; New York, USA: Palgrave Macmillian, 2003.

Data de submissão: 06/05/2019. Data de aprovação: 10/06/2019. 